\title{
PENGARUH KUALITAS PELAYANAN DAN KEPUASAN TERHADAP LOYALITAS KARYAWAN PADA PT. SEDERHANA ABADAN MITRA KAB. MADIUN
}

\author{
Ramadhan Prasetya Wibawa \\ Dosen Prodi. Pendidikan Ekonomi IKIP PGRI Madiun \\ Deny Ayu Tiarawati \\ Mahasiswa Prodi. Pendidikan Ekonomi IKIP PGRI Madiun
}

\begin{abstract}
Abstrak: Penelitian ini bertujuan untuk mengetahui kualitas pelayanan pada PT. Sederhana Abadanmitra, untuk mengetahui kepuasan kerja, untuk mengetahui loyalitas karyawan, adakah pengaruh kualitas pelayanan dan kepuasan kerja terhadap loyalitas karyawan pada PT. Sederhana Abadanmitra Kab. Madiun. Penentuan sampel dalam penelitian ini menggunakan sampel jenuh pada PT. Sederhana Abadanmitra Kab. Madiun sebanyak 79 karyawan.Metode kuesioner digunakan untuk memperoleh data kualitas pelayanan kepuasan kerja, dan loyalitas karyawan. Metode wawancara ditujukan kepada pimpinan PT. Sederhana Abadanmitra Kab. Madiun guna memperoleh ijin penelitian. Metode dokumen digunakan setelah diperoleh data berupa laporan kinerja dan standar operasional prosedur karyawan. Dalam menganalisis data digunakan metode statistik dengan rumus uji regresi linier berganda, uji r, uji F, uji t. Hasil penelitian ini menunjukkan bahwa kualitas pelayanan dan kepuasan kerja berpengaruh positif dan signifikan terhadap loyalitas karyawan pada PT. Sederhana Abadanmitra Kab. Madiun. Hal ini diperoleh dari hasil perhitungan regresi linier berganda sebesar $Y=10,329+1,014+0,204$, yang artinya adalah apabila kualitas pelayanan dan kepuasan kerja ditingkatkan satu kali akan terjadi peningkatan loyalitas kayawan sebanyak 11,548 apabila faktor lainnya tetap. Selain itu juga diperoleh hasil dari $r$ hitung sebesar 0,512 sedangkan $r$ tabel 0,220 yang menyatakan adanya penolakan Ho artinya kualitas pelayanan dan kepuasan kerja mempunyai hubungan dengan loyalitas karyawan. Selain itu juga diperoleh koefisien regresi (uji t) dengan nilai dari $t$ hitung yaitu 5,383 dan t tabel pada signifikansi 0,05 dengan uji dua pihak dan jumlah data dalam penelitian 79. Maka diperoleh $\mathrm{t}$ tabel sebesar 1,990. Hal ini berarti nilai $\mathrm{t}$ hitung $>\mathrm{t}$ tabel $(5,383>1,990)$. Dari kedua uji tersebut menyatakan adanya penolakan Ho yang artinya bahwa ada pengaruh antara kualitas pelayanan dan kepuasan kerja terhadap loyalitas karyawan pada PT. Sederhana Abadanmitra Kab. Madiun. Sedangkan untuk uji signifikansi $\mathrm{f}$ diperoleh hasil $\mathrm{f}$ hitung sebesar 144,168 dan $\mathrm{f}$ tabel sebesar 1,400 yang artinya bahwa f hitung $>$ f tabel $(144,168>1,400)$. Dari kedua uji tersebut menyatakan adanya penolakan Ho yang artinya bahwa ada pengaruh antara kualitas pelayanan dan kepuasan kerja terhadap loyalitas karyawan pada PT. Sederhana Abadanmitra Kab. Madiun.
\end{abstract}

Kata Kunci : Kualitas Pelayanan, Kepuasan Kerja, Loyalitas Karyawan

\section{PENDAHULUAN}

Perusahaan selain harus memperhatikan penjualan dari hasil produksinya, juga harus memperhatikan karyawannya. Hal ini sangat penting untuk dilakukan perusahaan agar keberlangsungan perusahaan dapat berjalan dengan lancar. Karyawan akan cenderung merasa nyaman bekerja pada perusahaan tersebut apabila pelayanan yang diberikan oleh perusahaan baik dan tidak hanya memforsir tenaga kerjanya saja namun juga memperhatikan kebutuhan karyawannya juga. 
Pada zaman sekarang ini, karyawan cenderung senang dengan pelayanan perusahaan yang mau memperhatikan kesejahteraan karyawannya dalam arti perusahaan memberikan perhatian khusus terhadap karyawannya dengan cara memberikan asuransi kerja, bonus dan tunjangan pada para karyawannya agar betah bekerja pada perusahaan tersebut dan memberikan yang terbaik bagi perusahaan.

Kualitas adalah totalitas fitur dan karakteristik produk atau jasa yang bergantung pada kemampuannya untuk memuaskan kebutuhan yang dinyatakan atau tersirat (Kotler dan Kevin, 2008:143).

Pelayanan adalah setiap tindakan atau kegiatan yang dapat ditawarkan oleh suatu pihak kepada pihak lain, yang pada dasarnya tidak berwujud dan tidak mengakibatkan kepemilikan apapun. Tingkat kepuasan pelanggan akan berdampak pada pendapatan lembaga dimana masyarakat memiliki pilihan kemana mereka hendak mendapatkan produk, program, dan layanan. (Kotler dan Nancy lee, 2007:195).

Dari pendapat diatas dapat disimpulkan bahwa kualitas pelayanan disini adalah segala bentuk aktivitas yang dilakukan oleh perusahaan guna memenuhi harapan pelanggan dan memberikan pelayanan yang terbaik bagi pelanggan. Pelayanan dalam hal ini diartikan sebagai jasa atau service yang disampaikan oleh pemilik jasa yang berupa kemudahan, kecepatan, hubungan, kemampuan dan keramahtamahan yang ditujukan melalui sikap dan sifat dalam memberikan pelayanan untuk kepuasan karyawan.

Ada dua faktor yang mempengaruhi kualitas layanan yaitu layanan yang diharapkan dan layanan yang dirasakan. Hal ini berarti citra kualitas yang baik bukanlah berdasarkan sudut pandang atau persepsi penyedia layanan melainkan dari sudut pandang atau persepsi karyawan. Untuk mencapai layanan umum yang berdayaguna dan berkualitas, maka perlu diterapkan prinsip-prinsip layanan sebagai berikut:

a. Proses dan prosedur harus ditetapkan dari awal.

b. Semua pihak harus memahami dan mematuhi proses dan prosedur.

c. Disiplin bagi pelaksana untuk mentaati proses dan prosedur

d. Perlu peninjauan proses dan prosedur oleh pimpinan, sewaktu-waktu dapat dirubah apabila ada perlu.

e. Perlu penciptaan iklim yang kondusif bagi pengembangan budaya organisasi untuk penciptaan kualitas layanan.

f. Kualitas berarti memenuhi keinginan, kebutuhan, dan selera konsumen.

g. Setiap orang dalam organisasi merupakan partner dengan orang lainnya.

Dalam pola pelayanan dibutuhkan beberapa syarat dalam melakukan pelayanan yang baik. Menurut (Kasmir, 2008: 232-234) ciri dari pelayanan yang baik adalah :

a. Tersedia sarana dan prasarana yang baik.

b. Tersedia personil yang baik

c. Bertanggungjawab pada nasabah sejak awal hingga selesai.

d. Mampu melayani secara cepat dan tepat.

e. Mampu berkomunikasi.

f. Menjanjikan jaminan kebersihan setiap transaksi.

g. Memiliki pengetahuan dan kemampuan yang baik.

h. Berusaha memahami kebutuhan nasabah.

i. Mampu memberikan kepercayaan pada nasabah.

Berdasarkan definisi di atas dapat disimpulkan bahwa pelayanan adalah proses pemberian bantuan yang diberikan oleh seseorang kepada orang lain yang tidak berwujud dan tidak berakibat pada pemilikan sesuatu pada jual beli barang atau jasa sehingga orang tersebut memperoleh sesuatu yang dinginkannya.

Kualitas pelayanan merupakan tingkat keunggulan yang diharapkan dan pengen- 
dalian atas tingkat keunggulan tersebut untuk memenuhi harapan pelanggan. Kualitas pelayanan keseluruhan ditentukan oleh kesesuaian keinginan yang dihasilkan dari perbandingan keinginan dan kinerja yang dirasakan konsumen. Kualitas layanan yang diberikan kepada konsumen menjadi tanggung jawab seluruh bagian pada perusahaan. Oleh sebab itu, rasa puas akan tercipta tergantung pada penyedia layanan dalam memenuhi harapan konsumennya secara konsisten.

Kepuasan kerja adalah derajat kepuasan yang dapat dirasakan oleh karyawan dalam memenuhi kebutuhan pribadi yang penting melalui pengalaman bekerja. Pemenuhan kebutuhan merupakan hal yang mendasar dari setiap tenaga kerja, dengan adanya kebutuhan yang tercukupi secara sadar akan meningkatkan kinerja dan loyalitas pegawai.

Kualitas pelayanan dalam penelitian ini berupa kompensasi yang diberikan oleh perusahaan kepada karyawan, baik itu hal pelayanan kesehatan maupun diberikannya cash bon kepada karyawan. Mengingat kebutuhan dari karyawan merupakan kebutuhan primer selain gaji tetap yang diberikan oleh perusahaan.

Menurut Robbins (2010:39) logis apabila mengasumsikan bahwa kepuasan kerja seharusnya menjadi determinan OCB seorang karyawan. Karyawan yang lebih puas akan mengutarakan hal positif tentang perusahaan, merk lain, dan melampaui ekspetasi kerja normal.

Kepuasan kerja sebagai satu pset sikap yang dipegang oleh individu mengenai pekerjaannya. Kepuasan kerja adalah pelahiran psikologikal individu terhadap pekerjaannya yaitu bagaimana individu itu melihat pekerjaannya. Sikap seorang pekerja boleh dibagikan kepada dua bagian yaitu sikap positif dan negatif. Pekerja yang bersikap positif adalah mereka yang mendapat kepuasan kerja. Manakala mereka yang bersikap negatif ialah mereka yang mengalami ketidak puasan kerja.

Menurut Wexly dan Yukl (dalam Wilson bangun, 2012 :237) kepuasan kerja merupakan generalisasi sikap-sikap terhadap pekerjaannya. Bermacam-macam sikap seseorang terhadap pekerjaannya mencerminkan pengalaman yang menyenangkan dan tidak menyenangkan dalam pekerjaannya serta harapan-harapannya terhadap pengalaman masa depan.

Menurut Robbins (dalam Sedarmayanti, 2011: 264) kepuasan kerja adalah "sikap umum terhadap pekerjaan seseorang yang menunjukkan perbedaan antara jumlah penghargaan yang diterima pekerja dan jumlah yang mereka yakini seharusnya mereka terima". Dan menurut Gibson (dalam Sedarmayanti, 2011: 264) kepuasan kerja adalah sikap yang dimiliki pekerja tentang pekerjaan mereka, hal tersebut merupakan hasil persepsi mereka tentang pekerjaan.

Kepuasan kerja merupakan respon afektif atau emosional terhadap berbagai segi atau aspek pekerjaan seseorang sehingga kepuasan kerja bukan merupakan konsep tunggal. Seseorang dapat relatif puas dengansalah satu aspek pekerjaan dan tidak puas dengan satu atau lebih aspek lainnya.

Kepuasan Kerja merupakan sikap (positif) tenaga kerja terhadap pekerjaannya, yang timbul berdasarkan penilaian terhadap situasi kerja. Penilaian tersebut dapat dilakukan terhadap salah satu pekerjaannya, penilaian dilakukan sebagai rasa menghargai dalam mencapai salah satu nilai-nilai penting dalam pekerjaan. Karyawan yang puas lebih menyukai situasi kerjanya daripada tidak menyukainya.

Kualitas pelayanan yang diberikan dengan baik akan menumbuhkan kepuasan kerja pada karyawan. Secara hal positif dan berkala akan meningkatkan kinerja dari karyawan itu sendiri. Kepuasan kerja muncul 
dari adanya perhatian dari pemilik perusahaan atas kebutuhan-kebutuhan mendasar yang dibutuhkan karyawan.

Dapat disimpulkan bahwa kepuasan kerja merupakan hasil dari tenaga kerja yang berkaitan dengan motivasi kerja. Kepuasan kerja secara keseluruhan bagi seorang individu adalah jumlah dari kepuasan kerja (dari setiap aspek pekerjaan) dikalikan dengan derajat pentingnya aspek pekerjaan bagi individu.

Faktor yang Mempengaruhi Kepuasan Kerja. Ada lima faktor yang dapat mempengaruhi kepuasan kerja menurut (Sedarmayanti, 2011:265-266) yaitu sebagai berikut :

1) Pemenuhan kebutuhan (Need fulfillment) Kepuasan ditentukan oleh tingkatan karakteristik pekerjaan memberikan kesempatan pada individu untuk memenuhi kebutuhannya.

2) Perbedaan (Discrepancies) Kepuasan merupakan suatu hasil memenuhi harapan. Pemenuhan harapan mencerminkan perbedaan antara apa yang diharapkan dan apa yang diperoleh individu dari pekerjaannya. Bila harapan lebih besar dari apa yang diterima, orang akan tidak puas. Sebaliknya individu akan puas bila menerima manfaat diatas harapan.

3) Pencapaian nilai (Value attainment) Kepuasan merupakan hasil dari persepsi pekerjaan memberikan pemenuhan nilai kerja individual yang penting.

4) Keadilan (Equity) Kepuasan merupakan fungsi dari seberapa adil individu diperlakukan di tempat kerja.

5) Komponen genetik (Genetic components) Kepuasan kerja merupakan fungsi sifat pribadi dan faktor genetik. Hal ini menyiratkan perbedaan sifat individu mempunyai arti penting untuk menjelaskan kepuasan kerja disamping karakteristik lingkungan pekerjaan.

Loyalitas karyawan secara umum dapat diartikan dengan kesetiaan, pengabdian dan kepercayaan yang diberikan atau ditujukan kepada seseorang atau lembaga, yang didalamnya terdapat rasa cinta dan tanggung jawab untuk berusaha memberikan pelayanan dan perilaku yang terbaik.

Loyalitas adalah kemauan bekerja sama yang berarti kesediaan mengorbankan diri, kesediaan melakukan pengawasan diri dan kemauan untuk menonjolkan kepentingan diri sendiri. Kesediaan untuk mengorbankan diri ini melibatkan adanya kesadaran untuk mengabdikan diri kepada perusahaan. Pengabdian ini akan selalu menyokong peran serta karyawan dalam perusahaan.

Menurut Mowday dan Steers (dalam Istijanto: 2012: 205) Komitmen merupakan loyalitas karyawan terhadap suatu unit sosial yang bisa berupa loyalitas karyawan terhadap perusahaan departemen, atau terhadap pekerjaan mereka.

Pemberian pelayanan tersebut merupakan reward dari adanya kepuasan pemilik usaha atas hasil yang diperoleh, dengan perolehan hasil maka gaji karyawan juga akan mengalami peningkatan yang signifikan. Dengan hal ini diharapkan karyawan akan bersifat loyal kepada perusahaan agar perusahaan dapat bertahan selama mungkin.

Dari adanya komitmen atau loyalitas karyawan menurut Istijanto juga akan memperoleh tingkatan loyalitas pelanggan hal ini diperkuat dari adanya pendapat dari Gunawan Adi Saputro (2010: 71-72) bahwa terdapat tingkat biaya investasi didalam menjaga loyalitas pelanggan:

1) Melakukan "basic marketing": perusahaan hanya berupaya menjual produknya.

2) Melakukan "reactive marketing" : di sini pemasar mendorong keberanian pelanggan untuk bersedia menghubungi perusahaan bilamana menghadapi kesulitan.

3) Melakukan "accountable marketing" disini perusahaan melakukan cheking dengan menanyakan kepada pelanggan apakah mereka merasa terpenuhi harapannya. 
4) Melakukan "proactive marketing”. Disini pemasar menghubungi pelanggan secara regular dalam waktu kewaktu.

5) Melakukan "partnership marketing". Yaitu bekerjasama secara teratur dan berlanjut dengan pelanggan-pelanggan yang besar dengan tujuan membantu mereka memperbaiki kinerja perusahaannya.

Berdasarkan uraian diatas dapat disimpulkan bahwa loyalitas kerja adalah suatu keadaan aktivitas yang menyangkut fisik, psikis dan sosial yang membuat individu mempunyai sikap untuk menaati peraturan yang ditentukan, melakukan dan mengamalkan sesuatu yang ditaatinya dengan penuh kesadaran dan tanggung jawab identifikasi personal terhadap upaya pencapaian tujuan perusahaan sesuai keahliannya sehingga peningkatan efektifitas perusahaan dan disertai dengan pengabdian yang kuat.

\section{METODE PENELITIAN}

Tempat penelitian ini dilakukan pada PT. Sederhana Abadanmitra Kab. Madiun. Alasan peneliti memilih tempat tersebut karena:

a. PT. Sederhana Abadanmitra Kab. Madiun mempunyai standar operasional prosedur yang bagus.

b. Sikap yang ramah dan pemberian izin penilitian terhadap peneliti.

c. Belum pernah ada penelitian di PT. Sederhana Abadanmitra Kab. Madiun mengenai kualitas pelayanan dan kepuasan kerja terhadap loyalitas karyawan.

\section{Populasi dan Sampel}

Secara umum populasi dapat diartikan keseluruhan subyekpenelitian sebagai sarana penelitian. Menurut Sugiyono (2009:215), bahwa"Populasi adalah wilayah generalisasi yang terdiri atas obyek atau subyek yang mempunyai kualitas dan karakteristik tertentu yang ditetapkan oleh peneliti untuk dipelajari dan kemudian ditarik kesimpulannya.". Maka populasi yang diteliti adalah 79 karyawan yang bekerja pada PT. Sederhana Abadan mitra Kab. Madiun. Demi kelancaran dalam penelitian ini, maka hanya mengambil sebagian sampel dari populasi yang ada. "Sampel adalah sebagian yang diambil dari populasi”'(Sudjana, 2005:6). Sample yang diambil adalah semua karyawan yang bekerja pada PT. Sederhana Abadanmitra Kab. Madiun. Penggunaan sample berdasarkan kesulurahan karyawan karena agar data yang didapat memiliki keabsahan dan realibel dengan penelitian yang dilaksanakan.

\section{Teknik Pengambilan Sampel}

Metode penentuan sampel yang di gunakan dalam penelitian ini adalah metode sampel jenuh. Metode sampel jenuh adalah teknik penentuan sampel bila semua anggota populasi di gunakan menjadi sampel. Dalam penelitian ini yang menjadi sample jenuh adalah keseluruhan karyawan PT. Sederhana Abadanmitra Kab. Madiun.

\section{Teknik Pengumpulan Data}

Data-data yang diperlukan untuk penelitian dikumpulkan dengan teknik pengumpulan data. Dalam penelitian ini teknik pengumpulan data yang digunakan dalam penelitian adalah :

a. Kuesioner

Iqbal Hasan (2012: 17) Kuesioner adalah cara pengumpulan data dengan menggunakan daftar pertanyaan atau angket atau daftar isian terhadap objek yang di teliti (populasi).

\section{b. Wawancara}

Wawancara adalah cara pengumpulan data dengan langsung mengadakan Tanya jawab kepada objek yang diteliti atau kepada perantara yang mengetahui persoalaan dari objek yang sedang diteliti (Iqbal Hasan, 
2012: 17).

c. Dokumentasi

Analisis dokumen ini dimaksudkan oleh peneliti agar dapat mengakuratkan data yang diperoleh sehinggga data yang diperoleh benar-benar valid.

\section{Analisis Pengambilan Data}

Metode analisis data merupakan cara yang utama digunakan untuk mengolah data yang terkumpul sehingga dapat menghasilkan suatu kesimpulan yang dapat dipertanggungjawabkan. Dalam penelitian ini menggunakan Analisis Regresi Linier Bergandadengan perhitungan Uji SPSS (Statistical Product and Service Solutions)for windows versi 17.0 dengan langkah:

1. Uji Validitas

2. Uji Reliabilitas

3. Uji Normalitas

4. Uji Asumsi Klasik

a. Uji Multikolinieritas

Multikolineritas timbul akibat adanya hubungan kausal antara dua variabel bebas atau lebih atau adanya kenyataan bahwa dua variabel penjelas atau lebih bersama-sama dipengaruhi oleh variabel ketiga yang berada di luar model. Uji ini digunakan untuk mendeteksi adanya multikolineritas, dilihat dari nilai Variance Inflation Faktor (VIF) tidak lebih dari 10 atau $<10$ maka model terbebas dari multikolineritas.

b. Uji Heterokedastisitas

Uji heterokedastisitas digunakan untuk mengetahui ada atau tidaknya penyimpangan asumsi klasik heterokedastisitas, yaitu adanya ketidaksamaan varian dari residual untuk semua pengamatan pada model regresi.

c. Uji Autokolerasi

Adryan Setyadharma (2010:4) mengemukakan bahwa uji ini digunakan untuk mendeteksi ada atau tidaknya klasik autokorelasi. Autokorelasi adalah korelasi yang terjadi diantara anggota observasi yang terletak berderetan, biasanya terjadi pada data time series. Untuk mendeteksi autokorelasi dapat dilakukan dengan uji Durbin Watson (DW) dengan ketentuan sebagai berikut :

5. Analisis Regresi Linier Berganda

6. Uji F

7. Ujit

\section{Variabel Penelitian}

Dalam penelitian ini yang Variabel bebas (X).

Adalah variabel yang tidak dipengaruhi oleh variabel lainya. Yang dipergunakan sebagai variabel bebas dalam penelitian ini terdiri dari 2 variabel yaitu :

Kualitas Pelayanan $\left(\mathrm{X}_{1}\right)$

Kepuasan Kerja $\left(\mathrm{X}_{2}\right)$

Dalam penelitian ini yang Variabel Terikat (Y)

Loyalitas Karyawan(Y)

\section{HASIL PENELITIAN \\ Uji Validitas}

Uji validitas dilakukan untuk mengukur sah atau tidaknya indikator atau kuesioner dari masing-masing variabel. Pengujian dilakukan dengan membandingkan $r$ hitung dan $r$ tabel. Nilai $r$ hitung merupakan hasil korelasijawaban responden pada masingmasing pertanyaan di setiap variabel yang dianalisis dengan program spss dan outputnya bernama corrected item correlation. Sedangkan untuk mendapatkan $r$ tabel dilakukan dengan tabel $r$ product moment, yaitu menentukan $\alpha=0,05$ kemudian $\mathrm{n}$ (sampel) $=$ 79 sehingga didapat nilai $r$ tabel dua sisi sebesar 0,220. Tingkat kevalidan indikator ataukuesioner dapat ditentukan, apabila $\mathrm{r}$ hitung $>\mathrm{r}$ tabel $=$ Valid dan $\mathrm{r}$ hitung $<\mathrm{r}$ tabel $=$ Tidak Valid. Hasil uji validitas selengkap 
nya dapat dilihat dari hasil perhitungan untuk 8 butir soal tiap variabel diketahui bahwa rhitung $>$ r tabel.

Dengan demikian indikator atau kuesioner yang digunakan oleh masingmasing variabel Kualitas Pelayanan, Kepuasan kerja terhadap loyalitas karyawan dinyatakan valid untuk digunakan sebagai alat ukur variabel.

\section{Uji Reliabilitas}

Uji reliabilitas digunakan untuk mengetahui apakah indikator atau kuesioner yang digunakan dapat dipercaya atau handal sebagai alat ukur variabel. Reliabilitas suatu indikator atau kuesioner dapat dilihat dari nilai cronbach'salpha $(\alpha)$, yaitu apabila nilai cronbach's alpha $(\alpha)$ lebih besar $(>)$ 0,22 makaindikator atau kuesioner adalah reliabel, sedangkan apabila nilai cronbach's alpha $(\alpha)$ lebih kecil $(<)$ 0,22 maka indikator atau kuesioner tidak reliabel. Secara keseluruhan hasil uji reliabilitas tiap variabel dinyatakan dapat dipercaya atau handal karena nilai cronbach's alpha lebih besar (>) darir tabel.

\section{Analisa RegresiLineier Berganda}

Atas dasar hasil pengolahan data diperoleh hasil persamaan regresi yaitu $\mathrm{Y}=$ $10,329+1,014+0,204$, yang artinya adalah apabila kualitas pelayanan dan kepuasan kerja ditingkatkan satu kali akan terjadi peningkatan loyalitas kayawan sebanyak 11,548 apabila faktor lainnya tetap.

\section{Uji Hipotesa}

\section{Hasil Uji Reabilitas}

Untuk uji reabilitas dari kualitas pelayanan diperoleh nilai $r_{\text {hitung }}$ adalah 0,295 sedangkan nilai $r_{\text {tabel }}$ sebesar 0,22 . Hal ini berarti bahwa $r_{\text {hitung }} \geq r_{\text {tabel }}(0,295 \geq 0,22)$. Dapat dikatakan bahwa $\mathrm{H}_{0}$ ditolak artinya terdapat hubungan yang signifikan kualitas pelayanan dan kepuasan kerja terhadap loyalitas karyapan pada PT. Sederhana Abadanmitra
Kab. Madiun.

Untuk uji reabilitas kepuasan kerja diperoleh nilai $r_{\text {hitung }}$ adalah 0,817 sedangkan nilai br $_{\text {tabel }}$ sebesar 0,22 . Hal ini berarti bahwa $r_{\text {hitung }} \geq r_{\text {tabel }}(0,817 \geq 0,22)$. Dapat dikatakan bahwa $\mathrm{H}_{0}$ ditolak artinya terdapat hubungan yang signifikan kualitas pelayanan dan kepuasan kerja terhadap loyalitas karyapan pada PT. Sederhana Abadanmitra Kab. Madiun.

Untuk uji reabilitas loyalitas karyawan diperoleh nilai $r_{\text {hitung }}$ adalah 0,512 sedangkan nilai $b_{\text {tabel }}$ sebesar 0,22 . Hal ini berarti bahwa $r_{\text {hitung }} \geq r_{\text {tabel }}(0,512 \geq 0,22)$. Dapat dikatakan bahwa $\mathrm{H}_{0}$ ditolak artinya terdapat hubungan yang signifikan kualitas pelayanan dan kepuasan kerja terhadap loyalitas karyawan pada PT. Sederhana Abadanmitra Kab. Madiun

\section{Hasil Uji t \\ Pengaruh Kualitas Pelayanan Terhadap Loyalitas Karyawan}

Hasil uji t antara kompensasi terhadap Kepuasan Kualitas pelayanan terhadap loyalitas karyawan dapat dilihat hasilnya sebagai berikut :

Nilai t hitung Kualitas Pelayanan terhadap loyalitas karyawan sebesar 3.921, sementara untuk $\mathrm{t}$ tabel dengan sig. $\alpha=0,05$ dan $\mathrm{df}=\mathrm{n}-\mathrm{k}$, yaitu 79-1=78, maka didapat $\mathrm{t}$ tabel satu sisi sebesar 1,990. Nilai t hitung lebih besar dibanding $\mathrm{t}$ tabel, hal ini menunjukkan Ho ditolak artinya ada beda pengaruh antara Kualitas Pelayanan dan kepuasan kerja terhadap Loyalitas Karyawan dinyatakan baik.

\section{Pengaruh Kualitas Pelayanan dan Kepu- asan Kerja Terhadap Loyalitas karyawan}

Hasil uji t antara Kualitas Pelayanan dan Kepuasan Kerja terhadap loyalitas karyawan dapat dilihat hasilnya sebagai berikut:

Nilai $t$ hitung Kualitas Pelayanan terhadap kepuasan kerja sebesar 2,774 
sementara untuk $\mathrm{t}$ tabel dengan sig. $\alpha=0,05$ dan $\mathrm{df}=\mathrm{n}-\mathrm{k}$, yaitu 79-2=77, maka didapat $\mathrm{t}$ tabel satu sisi sebesar 1,664. Nilai t hitung lebih besar dibanding $t$ tabel, hal ini menunjukkan diterimanya Ha2 yang menyatakan ada pengaruh positif dan signifikan antara Kualitas Pelayanan terhadap Loyalitas karyawan.

Nilai t hitung Kepuasan Kerja terhadap loyalitas karyawan sebesar 5,720 sementara untuk $\mathrm{t}$ tabel dengan sig. $\alpha=0,05 \mathrm{dan} \mathrm{df}=\mathrm{n}-\mathrm{k}$, yaitu 79-2=77, maka didapat $\mathrm{t}$ tabel satu sisi sebesar 1,664. Nilai $t$ hitung lebih besar disbanding $\mathrm{t}$ tabel, hal ini menunjukkan diterimanya Ha3 yang menyatakan ada pengaruh positif dan signifikan antara Kepuasan Kerja terhadap kepuasan kerja.

\section{Hasil Uji Fisher}

\section{Hasil uji F Kualitas Pelayanan Terhadap Loyalitas Karyawan}

Hasil uji F antara Kualitas Pelayanan terhadap loyalitas karyawan dapat dilihat hasilnya pada tabel berikut:

F hitung sebesar 15,376, sementara $F$ tabel dengan df1 dan df2=79-1-1=77, maka didapat $F$ tabel 3,115. Nilai $F$ hitung lebih besar dibanding Ftabel dengan demikian model regresi antara Kualitas Pelayanan terhadap Kepuasan Kerja dinyatakan baik.

\section{Hasil uji F Kualitas Pelayanan dan Kepu- asan Kerja Terhadap Loyalitas karyawan}

Hasil uji F antara Kualitas Pelayanan dan Kepuasan Kerja terhadap kepuasan kerja dapat dilihat hasilnya pada tabel berikut:

$\mathrm{F}$ hitung sebesar 32,010, sementara $\mathrm{F}$ tabel dengan df1 dan df2=79-2-1=76, maka didapat $F$ tabel 3,115. Nilai $F$ hitung lebih besar dibanding Ftabel dengan demikian model regresi antara Kualitas Pelayanan dan Kepuasan Kerja terhadap kepuasan kerja dinyatakan baik.

\section{Simpulan Hasil Analisis}

Atas dasar hasil pengujian hipotesis dapat diambil simpulan sebagai berikut:

\section{PEMBAHASAN \\ Pembahasan Uji Reabilitas}

Untuk uji reabilitas dari kualitas pelayanan diperoleh nilai $r_{\text {hitung }}$ adalah 0,295 sedangkan nilai $r_{\text {tabel }}$ sebesar 0,22 . Hal ini berarti bahwa $r_{\text {hitung }} \geq r_{\text {tabel }}(0,295 \geq 0,22)$. Dapat dikatakan bahwa $\mathrm{H}_{0}$ ditolak artinya terdapat hubungan yang signifikan kualitas pelayanan dan kepuasan kerja terhadap loyalitas karyawan pada PT. Sederhana Abadanmitra Kab. Madiun.

Untuk uji reabilitas kepuasan kerja diperoleh nilai $r_{\text {hitung }}$ adalah 0,817 sedangkan nilai br $r_{\text {tabel }}$ sebesar 0,22 . Hal ini berarti bahwa $r_{\text {hitung }} \geq r_{\text {tabel }}(0,817 \geq 0,22)$. Dapat dikatakan bahwa $\mathrm{H}_{0}$ ditolak artinya terdapat hubungan yang signifikan kualitas pelayanan dan kepuasan kerja terhadap loyalitas karyawan pada PT. Sederhana Abadanmitra Kab. Madiun.

Untuk uji reabilitas loyalitas karyawan diperoleh nilai $r_{\text {hitung }}$ adalah 0,512 sedangkan nilai $b_{\text {tabel }}$ sebesar 0,22. Hal ini berarti bahwa $r_{\text {hitung }} \geq r_{\text {tabel }}(0,512 \geq 0,22)$. Dapat dikatakan bahwa $\mathrm{H}_{0}$ ditolak artinya terdapat hubungan yang signifikan kualitas pelayanan dan kepuasan kerja terhadap loyalitas karyawan pada PT. Sederhana Abadanmitra Kab. Madiun.

\section{Pembahasan Uji Fisher}

Untuk uji Fisher diperoleh hasil nilai $F_{\text {hitung }}$ sebesar 32,010 sedangkan nilai $F_{\text {tabel }}$ sebesar 3,115. Dilain pihak apabila dilihat dari nilai $\mathrm{Sig}_{\text {hit }}$ sebesar 0,000 dan nilai Sig $_{\text {prob }}$ besarnya 0,05 . Hal ini berarti bahwa $F_{\text {hitung }} \geq$ $F_{\text {tabel }}(32,010 \geq 3,115)$ atau $\operatorname{Sig}_{\text {hit }} \leq \operatorname{Sig}_{\text {prob }}(0,000$ $\leq 0,05)$. Dengan demikian $\mathrm{H}_{0}$ ditolak, artinya ada pengaruh kualitas pelayanan dan 
kepuasan kerja terhadap loyalitas PT. Sederhana Abadanmitra Kab. Madiun.

\section{Pembahasan Uji t}

Untuk uji $\mathrm{t}$ diperoleh hasil sebagai berikut:

Nilai $t_{\text {hitung }}$ kualitas pelayanan terhadap kepuasan kerja sebesar 2,774 dengan $\mathrm{Sig}_{\text {hit }}$ sebesar 0,000, sedangkan $\mathrm{t}_{\mathrm{tab}} 0,05$ didapat $\mathrm{t}_{\mathrm{tab}}$ dalam satu sisi sebesar 1,664. Hal ini dapat dikatakan $\mathrm{t}_{\text {hitung }} \geq \mathrm{t}_{\text {tabel }}(2,774 \geq 1,664)$ atau atau $\mathrm{Sig}_{\text {hit }} \leq \operatorname{Sig}_{\text {prob }}(0,000 \leq 0,05)$. Keadaan ini dikatakan ada pengaruh positif dan signifikan antara kualitas pelayanan terhadap kepuasan kerja.

Nilai $t_{\text {hitung }}$ kepuasan kerja terhadap loyalitas karyawan sebesar 5,720 dengan Sig $_{\text {hit }}$ sebesar 0,000 , sedangkan $\mathrm{t}_{\text {tab }} 0,05$ didapat $t_{\text {tab }}$ dalam satu sisi sebesar 1,664. Hal ini dapat dikatakan $t_{\text {hitung }} \geq t_{\text {tabel }}(5,720 \geq 1,664)$ atau $\operatorname{Sig}_{\text {hit }} \leq \operatorname{Sig}_{\text {prob }}(0,000 \leq 0,05)$. Keadaan ini dapat dikatakanada pengaruh kepuasan kerja terhadap loyalitas karyawan pada PT. Sederhana Abadanmitra Kab. Madiun.

Dari hasil penelitian diketahui bahwa kualitas pelayanan dan kepuasan kerja berpengaruh terhadap loyalitas karyawan. Artinya suatu perusahaan harus bias memberikan pelayanan khusus terhadap karyawannya agar karyawan merasakan kepuasan dan punya sifat yang loyal terhadap perusahaan.

\section{PENUTUP}

\section{Simpulan}

Kesimpulan dari penelitian mengenai pengaruh Kualitas Pelayanan terhadap Kepuasan Kerja serta implikasinya pada Loyalitas karyawan PT. Sederhana Abadanmitra adalah sebagai berikut:

1. Nilai t hitung Kualitas Pelayanan terhadap loyalitas karyawan PT. Sederhana Abadanmitra Kab. Madiun sebesar 2,774 sementara untuk $t$ tabel dengan sig. $\alpha=0,05$ dan $\mathrm{df}=\mathrm{n}-\mathrm{k}$, yaitu 79-2=77, maka didapat $\mathrm{t}$ tabel satu sisi sebesar 1,664. Nilai t hitung lebih besar dibanding t tabel, hal ini menunjukkan diterimanya Ha yang menyatakan ada pengaruh positif dan signifikan antara Kualitas Pelayanan terhadap Loyalitas karyawan.

2. Nilai t hitung Kepuasan Kerja terhadap loyalitas karyawan PT. Sederhana AbadanmitraKab. Madiunsebesar 5,720 sementara untuk $\mathrm{t}$ tabel dengan sig. $\alpha=0,05$ dan $\mathrm{df}=\mathrm{n}-\mathrm{k}$, yaitu $79-2=77$, maka didapat $t$ tabel satu sisi sebesar 1,664. Nilai $t$ hitung lebih besar dibanding $t$ tabel, hal ini menunjukkan diterimanya Ha yang menyatakan ada pengaruh positif dan signifikan antara Kepuasan Kerja terhadap kepuasan kerja.

3. Ada pengaruh kualitas pelayanan dan kepuasan kerja terhadap loyalitas karyawan PT. Sederhana Abadanmitra Kab. Madiun berdasarkan hasil analisis regresi linier berganda diketahui bahwa kualitas pelayanan dan kepuasan kerja berpengaruh signifikan terhadap loyalitas karyawan. Jadi ada pengaruh kualitas pelayanan dan kepuasan kerja terhadap loyalitas karyawan pada PT. Sederhana Abadanmitra Kab. Madiun. Dapat dibuktikan untuk $t$ hitung Kualitas Pelayanan terhadap kepuasan kerja sebesar 2,774 sementara untuk $t$ tabel dengan sig. $\alpha=0,05$ dan $\mathrm{df}=\mathrm{n}-\mathrm{k}$, yaitu 79-2=77, maka didapat $t$ tabel satu sisi sebesar 1,664. Ho ditolak, Ha diterima jika thitung $>\mathrm{t}$ tabel, nilai thitung $>\mathrm{t}$ tabel yaitu 2,229. Untuk nilai t hitung Kepuasan Kerja terhadap loyalitas karyawan sebesar 5,720 sementara untuk $t$ tabel dengan sig. $\alpha=0,05$ dan $\mathrm{df}=\mathrm{n}-\mathrm{k}$, yaitu $79-2=77$, maka didapat $t$ tabel satu sisi sebesar 1,664. Ho tolak, Ha diterima jika $\mathrm{t}$ hitung $>\mathrm{t}$ tabel nilai $t$ hitung $>t$ tabel yaitu 5,720 $>1,664$ sehingga ada pengaruh kualitas pelayanan dan kepuasan kerja terhadap loyalitas 
karyawan. Sedangkan untuk uji signifikansi f diperoleh hasil f hitung sebesar 32,010 dan f tabel sebesar 3,115 yang artinya bahwa f hitung $>\mathrm{f}$ tabel $(32,010>$ $3,115)$.

Dari kedua uji tersebut menyatakan adanya penolakan Ho yang artinya bahwa ada pengaruh antara kualitas pelayanan dan kepuasan kerja terhadap loyalitas karyawan pada PT. Sederhana Abadanmitra Kab. Madiun.

\section{Saran}

Saran yang bisa disampaikan dari hasil penelitian yang didapat adalah sebagai berikut :

1. Pada faktor Kepuasan Kerja masih perlu adanya peningkatan Loyalitas Karyawan. PT. Sederhana Abadanmitra Kab. Madiun dapat meningkatkan loyalitas dengan cara:

a. Perhatian khusus kepada karyawan Ini bisa diimplementasikan dengan cara menaikan jabatan dan meningkatkan gaji.

b. Membangun nilai kekeluargaan

Nilai ini bisa dibangun dengan cara makan siang bersama karyawan terpilih. Tidak perlu setiap hari, makan siang bersama bisa dilakukan dalam satu bulan atau seminggu sekali.

2. Maraknya jenis usaha yang sama memberikan Kualitas Pelayanan murah dan Kualitas Pelayanan yang prima, PT. Sederhana Abadanmitra harus siap bersaing dengan cara :

a. Ketepatan waktu pelayanan.

b. Akurasi pelayanan.

c. Kesopanan dan keramahan dalam memberikan pelayanan, harus ditingkatkan dan diutamakan, bagi mereka yang berinteraksi langsung dengan pelanggan eksternal, seperti operator telepon, petugas keamanan, kasir, penerima tamu dan lain-lain. d. Tanggung jawab. Berkaitan dengan penerimaan pesanan dan penanganan keluhan dari pelanggan eksternal.

e. Kelengkapan, menyangkut lingkup pelayanan dan ketersediaan sarana pendukung, serta pelayanan komplementer lainnya.

f. Kemudahan mendapatkan pelayanan. Kemudahan ini berkaitan dengan banyaknya outlet, serta banyaknya Kualitas Pelayanan pendukung seperti komputer untuk memproses data dan lain-lain.

g. Variasi model pelayanan. Yang berkaitan dengan inovasi untuk memberikan pola pola baru dalam pelayanan, dan features dari pelayanan.

h. Pelayanan pribadi. Berhubungan dengan fleksibilitas dan penanganan permintaan khusus.

\section{DAFTAR PUSTAKA}

Andryan Setyadarma. 2010. Uji Asimsi Klasik dengan SPSS 16.0. Universitas Negeri Semarang. Semarang.

Fandy Tjiptono. 2004. Pemasarann Jasa. Malang: Bayu Media Publishing.

Gunawan Adi Saputro. 2010. Manajemen Pemasaran Analisis untuk Perancangan Strategi Pemasaran. Yogyakarta: STIM. YKPN.

Hasan, Iqbal. 2012. Analisis Data Penelitian dengan Statistik. Jakarta: BumiAksara.

Husein Umar, 2011. Metode Penelitian untuk skripsi dan tesis bisnis. Jakarta: Rajawali Pers.

Husein Umar. 2003. Metode Riset Bisnis. Jakarta: Gramedia.

Istijanto. 2012. Riset Sumber Daya Manusia Cara mendeteksi dimensi-dimensi kerja karyawan. Jakarta: Gramedia. 
Kasmir. 2008. Manajemen Perbankkan. Jakarta: Rajawali.

Kotler, Philip. Kevin Lane Keller. 2008. Manajemen Pemasaran. Jakarta: Erlangga.

Kotler, Philip. Lee, Nancy. 2007. Pemasaran Disektor Publik. Jakarta: PT Macanan Jaya Cemerlang.

Sedarmayanti. 2011. Membangun dan Mengembangkan Kepemimpinan Serta Meningkatkan Kinerja Untuk Meraih Keberhasilan. Bandung: Aditama.

Stephen P. Robbinson. Mary Coulter. 2010. Manajemen. Jakarta: Erlangga.

Sudjana. 2005. Metode Statistika. Bandung: PT. Tarsito.
Sugiyono. 2006. Metode Penelitian Kuantitatif, Kualitatif dan $R \& D$. Bandung: Alfabeta

Sugiyono. 2009. Metode Penelitian Kuantitatif, Kualitatif dan $R \& D$. Bandung: Alfabeta

Suharsimi Arikunto. 2010. Prosedur penelitian suuatu pendekatan praktik. Jakarta: Reneka Cipta.

TIM Penyusun Microsoft. 2007. Praktikum Metode riset untuk bisnis dan manajemen. Jakarta: Widyatama.

Wilson Bangun. 2012. Manajemen Sumber Daya Manusia. Jakarta: Erlangga.

Yusuf Wibisono. 2005. Metode Statistik. Yogyakarta: Gajah Mada University Press. 